\title{
Circular economy as a way of sustainable production and consumption
}

\author{
Brigita Boorová1,** \\ ${ }^{1}$ Department of Production Management and Logistics, Faculty of Business Management, University \\ of Economics in Bratislava, Dolnozemska cesta 1, 85235 Bratislava, Slovakia
}

\begin{abstract}
The paper deals with a circular economy as a way of sustainable production and consumption. The introductory part describes the basic features of circular and linear economics as well as their differences. The linear economy is based on the principle of "exploit produce - discard". The aim of the circular economy is to preserve the value of products and materials for as long as possible, to minimize waste and to conserve natural resources. The paper presents examples of good practice of business entities and self-governments whose activities are in accordance with the principles of the circular economy.
\end{abstract}

\section{Introduction}

Our lifestyle is focused on consuming as much as possible, and we can say that we have been living in a linear economy since the industrial revolution. In a linear economy, predominantly single-use products are produced, resulting in the disproportionate depletion of non-renewable natural resources, the production of huge amounts of waste, and the associated degradation and pollution that results in climate change. This one-way economic model applies in production to the extraction of natural resources, which serve as production inputs, and are then used in the material flow in the mass production of products that are pushed to consumer markets. For consumption, most of these mass-produced products are for single use and are usually disposed of after use. This one-way mass production and consumption model is unsustainable and we are beginning to feel its impact. The transition to a circular economy is a way of sustainable production and consumption.

\section{Characteristics of the circular economy}

The circular economy is a useful and regenerative design of an economic model, which means the constant maintenance of raw materials, materials, and products in their useful position, within the life cycle. Common sources of raw materials are being depleted all over the world. This model uses waste to create new sources of raw materials and increases the circular economy. In the traditional economy, everything is direct, resp. in the line, from the

\footnotetext{
${ }^{*}$ Corresponding author: brigita.boorova@euba.sk
} 
extraction of raw materials through production and consumption to waste. The circular economy is more environmentally friendly, making it more suitable for our country. [15] The currently popularized concept of the circular economy expands the possibilities of reuse and recycling of conventional waste and by-products, by emphasizing the use of value built into waste materials. [1, 9, 15, 2, 17] The new concept of the circular economy, promoted by the business community, is assessed in terms of the concept and scientific research of sustainable development. In particular, sustainability science. [3,11]

The model of circular economy is an in-depth analysis of a case study over a 30 -year period, highlighting the successes, difficulties, and conflicts of adopting a circular economy model. The case study is based on interviews, key documents and information from customers. The findings demonstrate how sustained circular economy business practices can deliver significant new revenues, resource productivity, and business continuity benefits, but also require managers and practitioners to develop competencies and capabilities, such as balancing linear and circular systems, to address complex and highly dynamic factors, including rapid technological shifts and market volatility. [6]

\subsection{Circular economics versus linear economics}

Circular economics

According to the Institute of Circular Economics SR [7], the circular economy is a sustainable development strategy that creates functional and healthy relationships between nature and human society. By perfectly closing the flows of raw materials and materials in the long cycles shown in figure 1, it opposes the current linear system, where the raw materials are transformed into products, sold and burned or landfilled at the end of their life.

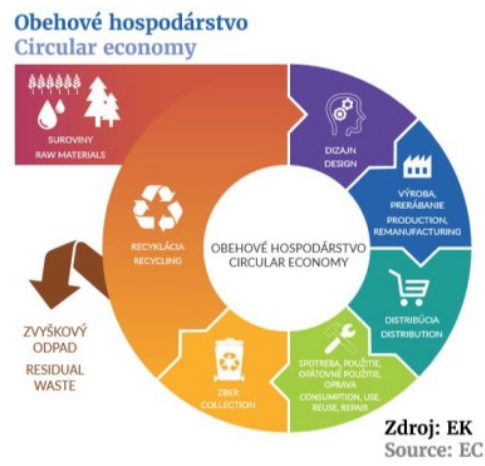

Fig. 1. Circular economics. [4]

Its basic principles are based on the idea that all raw material, material and product flows can be re-integrated into the life cycle after their use, where they become a source of resources for new products and services. While the replacement of primary materials by secondary ones may offer part of the solution, recycling is not a final and at the same time attractive solution, as its processes are energy-intensive and generally involve the degradation of materials. All this leads to an increase in demand for original materials. The circular economy goes beyond recycling, as it is based on a renewable industrial system leading to the elimination of waste. Recycling can be understood as the outer packaging of the entire circular economy, requiring greater energy consumption than the inner packaging of the circular economy, which means, above all, repair/modification, reuse, or processing. The aim is not only to improve the life cycle and use of the product itself but also to minimize energy consumption. 


\section{Linear economics}

But companies usually operate on the principle of a linear economy. This means a one-way economy based on consumption, the sequence of which is shown in figure 2. In principle, the initial minerals are extracted, then enter the transformation process, where they are mainly mass production into a product that travels through distribution channels to $\mathrm{B} 2 \mathrm{~B}$ or $\mathrm{B} 2 \mathrm{C}$. If it is $\mathrm{B} 2 \mathrm{~B}$, it means from business to business for further processing, such as semifinished products, unfinished products, material, etc. Within $\mathrm{B} 2 \mathrm{C}$, the product travels to the end customer for final consumption. Products in a linear economy are either disposable or short-lived. At the end of their service life, they end up as waste, in the conditions of the Slovak Republic mostly in landfills.
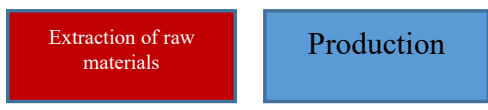

Fig. 2. Linear economics. [7]
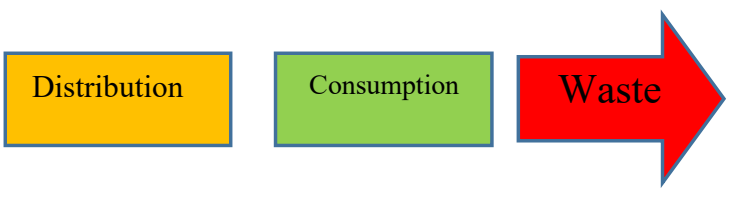

This type of economy does not follow the principles of sustainability, it is based on the disproportionate extraction of minerals, on massive production, of which the products are mostly of poor quality and do not have a long life. Massive (almost 24 hours) production, as well as distribution associated with logistics and massive consumption, resulting in the depletion of minerals, consumption of huge amounts of energy, waste of resources as well as the waste of products and especially the generation of large amounts of waste of all categories throughout the process.

Monitoring the progress of the goals in the area of the transition to a circular economy is necessary but also a challenging task. It is also challenging because this transition is a systemic change that affects the whole economy and includes almost all products and services. The monitoring framework aims to measure progress towards a circular economy so as to cover individual aspects at all stages of the life cycle of resources, products, and services. [5]

\section{Research design}

The main goal of the paper is to describe the basic characteristics of the circular economy, to describe its difference from the linear economy, and to give examples of good practice used by the circular economy in Slovakia. The introductory part of the paper describes the basic characteristics of concepts that are related to the issue and relate to the circular economy. Subsequently, we gave examples of good practice of business entities and local governments, whose activities are in accordance with the principles of the circular economy. We used classical methods of analysis, synthesis, induction, and deduction to process information and knowledge in the paper.

\section{Results and Discussion}

It is clear that the current linear model of economic growth no longer meets the needs of today's society and cannot sufficiently reflect on the problems associated with it. To ensure sustainable growth on a global scale as well as at the EU level, resources need to be used in a smarter, more sustainable way. One of the efforts of the world community to address these issues in 2015 was the adoption of the 2030 Agenda for Sustainable Development. This document, adopted by the United Nations (UN), defines a total of 17 goals with a priority on Goal 12 to ensure sustainable consumption and production patterns, which 
defines the needs of the communities and economies of the countries in order to mitigate, respectively, eliminate existing and projected problems with the availability of natural resources on a global scale. Other selected goals also deal with the change of production models, the development of new technologies, as well as other forms of innovation. In 2015, the European Commission adopted an ambitious package of rules on the circular economy. The focus is on the EU Circular Economy Action Plan, with measures for the entire product life cycle: from design, resources, production, and consumption to waste management and the secondary raw materials market. The aim of the circular economy is to preserve the value of products and materials for as long as possible in order to minimize waste and the use of new resources. The transition to a circular economy supports the fulfilment of the main objective of the Resource Efficiency Program under the Europe 2020 Strategy for Smart, Sustainable, and Inclusive Growth. The shift towards a circular economy means, in addition to reducing the negative impact on the environment, also increasing the security of supply of raw materials, strengthening competitiveness and innovation, and thus higher growth and job creation. Monitoring the progress of the objectives in the area of the transition to a circular economy is a necessary but also challenging task. It is also challenging because this transition is a systemic change that affects the whole economy and includes almost all products and services. The monitoring framework aims to measure progress towards the circular economy so as to cover individual aspects at all stages of the life cycle of resources, products, and services. In January 2018, the European Commission proposed a list of indicators to measure progress. The list consists of a set of indicators grouped into four phases and aspects of the circular economy: 1) production and consumption, 2) waste management, 3) secondary raw materials, 4) competitiveness and innovation. In general, this copies the logic and structure of the EU Circular Economy Action Plan. [5]

In the article, we will then focus on the phase and aspect of the circular economy no. 1) Production and consumption.

Changes in production and consumption (processed according to [5]) are a necessity in the introduction of the circular economy. Emphasis must be placed on the circulation of products when they are created. At the same time, the sectors of the economy that produce and consume materials and products, as well as households, need to reduce the amount of waste they generate. For production and consumption, progress is monitored in the areas of:

- supply of critical raw materials,

- voluntary environmental tools,

- waste generation,

- food waste.

\subsection{Examples of good practice of selected business entities and local governments, whose activities are in accordance with the principles of circular economy}

Not only is the business community aware of the need for sustainable consumption and production, as well as maintaining a suitable environment for future generations. The following section provides examples of good practice.

Green County

Green County in the Trenčín Self-Governing Region aims to reduce its ecological footprint and increase the environmental awareness of the region's inhabitants. Green County is so far the only project of its kind in Slovakia at the regional level at all. The project is divided into the following areas:

- energy saving,

- electromobility support, 
- environmental education,

- electronic county,

- bicycle paths and cycle paths. [16]

Circulation Slovakia platform

Seven partners from the public, private, and non-governmental sectors established the Circulation Slovakia platform in 2019. In December, 2019, they signed a memorandum of cooperation on the premises of the Ministry of the Environment of the Slovak Republic. The platform aims to contribute to the transition to a circular economy that conserves natural resources, minimizes waste, reduces dependence on imports of primary raw materials, and provides new business opportunities. The founding members of the Circulation Slovakia platform are the Ministry of the Environment of the Slovak Republic, the Embassy of the Kingdom of the Netherlands, Slovak Business Agency (SBA), PricewaterhouseCoopers Slovakia, the Institute of Circular Economics (INCIEN), the Slovak Environment Agency and the Dutch Chamber of Commerce in Slovakia. [8]

Voluntary tools of the environmental policy used in selected enterprises

The use (application) of voluntary tolls of the environmental policy is one of the principles of the circular economy, as they are of great importance in influencing consumption and production and at the same time can be its driving force. The most frequently used in Slovakia are EMS (Environmental Management System) according to ISO 14001 and EMAS (Eco-Management and Audit Scheme), Environmental Labelling of products and services (Ecolabelling). The Slovak Environment Agency, the Department of Environmental Management and the Basel Convention in Bratislava, which also acts as the competent authority for the EMAS scheme, participate in their implementation.

Ecomanagement and Audit Scheme (EMAS) is a voluntary environmental management tool for companies that want to enhance and improve their environmental performance. By implementing the scheme, companies declare compliance with environmental legislation, local responsibility, and active involvement of employees, reliability, and credibility of published environmental information. The aim of the EMAS scheme for businesses is the continuous improvement of environmental behaviour, which is monitored in six areas of the environment, namely energy efficiency, material efficiency, water, waste, biodiversity, and emissions. They are required to publish to the general public and other interested parties in the Environmental Statement throughout the registration period. EMAS is a reliable and effective management tool on the market for companies that want to improve their environmental performance through added value compared to the requirements of environmental management systems according to the international standard EN ISO 14001, in particular:

- in accordance with environmental legislation, the implementation of which is guaranteed by the state,

- mandatory information to the public through the organization's environmental statement,

- increased employee engagement. [12]

The following business entities are currently registered in the EMAS scheme with their registered office in the Slovak Republic:

- SEWA, a. s., Bratislava (engineering services in the field of collection, treatment, and recycling of electrical waste and waste),

- ŽOS - EKO, s. r. o., Vrútky (social services in the field of waste management),

- EUROVIA SK, a. s., Košice (construction sector),

- PROSPECT, s. r o., Nové Zámky (construction sector), 
- STRABAG, s. r.o., Bratislava (construction sector),

- VÁHOSTAV - SK, a.s., Bratislava (construction sector),

- PORR, s.r.o., Bratislava (construction sector),

- SKANSKA SK, a.s., Bratislava (construction sector),

- CED Consulting, s.r.o., Bratislava (construction sector),

- AVA - stav, s.r.o., Galanta (construction sector),

- FERRMONT, a.s., Púchov (water and air technologies). [10]

The National Eco-friendly Product label scheme has been in place in our country since 1997. It refers to products or services based on an assessment of their entire life cycle that is less harmful to the environment than their alternatives. After Slovakia's accession to the EU, the EU Ecolabel (formerly the European Flower) is awarded through the European scheme. For companies with an environmental mindset, Ecolabelling is a suitable marketing tool that can strengthen their market position and gain a competitive advantage. The schemes are intended for promotion and represent an important information tool for environmental and consumer policy. Under the national scheme, the following companies are currently granted the right to use the national label "Environmentally Friendly Product":

- Johan ENVIRO s.r.o. Bratislava: for products belonging to the product group "Sorption materials",

- CRH (Slovensko), a. s. Turňa nad Bodvou: for products belonging to the product group "Cement",

- Maccaferri Manufacturing Europe s. r. o. Senica: for products belonging to the product group "Gabion, Terramesh, Reno Mattresses". [13]

Under the European scheme, the following company is currently granted the right to use the "EU Ecolabel" in the Slovak Republic:

- SLOVENSKÁ GRAFIA, a.s. Bratislava: for products belonging to the product group "Printed paper". [14]

\section{Conclusion}

The paper deals with the circular economy as a way of sustainable production and consumption. In the introductory part, we characterized the analysed issues and described the basic features of circular and linear economics, as well as their differences. Subsequently, we gave examples of good practice of business entities and local governments, whose activities are in accordance with the principles of the circular economy.

The linear economy is based on the principle of "extract - produce - discard". This type of economy does not follow the principles of sustainability, it is based on the disproportionate extraction of minerals and massive production, from which the products do not have a long life and after their end they become waste.

The aim of the circular economy is to preserve the value of products and materials for as long as possible in order to minimize waste and the use of new resources. Its basic principles are based on the reintegration of material and product flows into the life cycle after their use, where they become sources (raw materials) for new products and services, i.e. waste generation and environmental pollution are partially or completely eliminated.

Good examples of the practice of selected business entities that eliminate their impact on the environment and adhere to the principles of the circular economy are companies that use voluntary instruments of environmental policy, such as. EMAS and Ecolabelling scheme. The use of voluntary environmental policy instruments in enterprises is linked to the transition to a circular economy, as these instruments are linked to its principles. These 
tools are of great importance in influencing consumption and production and guarantee their sustainability.

\section{Acknowledgement}

This paper is an outcome of research project: „Socio-economic determinants of sustainable consumption and production in terms of impact on performance competitiveness of enterprises“, VEGA no. 1/0708/20 - project share is $100 \%$; led by doc. Ing. Daniela Rybárová, $\mathrm{PhD}$.

\section{References}

1. F. M. Asif, M. Lieder, A. Rashid, Multi-method simulation based tool to evaluate economic and environmental performance of circular product systems. Journal of Cleaner Production, 139, 1261-1281 (2016)

2. B. CH. Barman, Role of Green Economy in the Context of Indian Economy. Published in International Journal of Trend in Scientific Research and Development (ijtsrd), ISSN: 2456-6470, Volume-2, Issue-1, (2017)

3. G. Broman, K. Robèrt, T. J. Collins, G. Basile, R. J. Baumgartner, T. Larsson, D. Huisingh, Science in support of systematic leadership towards sustainability. Journal of Cleaner Production, 140, 1-9. (2017)

4. European Commission, https://ec.europa.eu/, (2020)

5. T. Guštafíková, A. Kostúriková, Z. Lieskovská, Obehové hospodárstvo - budúcnost' rozvoja Slovenska. Ministerstvo životného prostredia Slovenskej republiky, Slovenská agentúra životného prostredia. 12 -28. (2019)

6. P. Hopkinson, M. Zils, P. Hawkins, S. Roper, Managing a Complex Global Circular Economy Business Model: O PPORTUNITIES AND C HALLENGES. California Management Review 2018, (C) The Regents of the University of California, 60 (3) 71 94 (2018)

7. Inštitút cirkulárnej ekonomiky (ICE), Cirkulárna ekonomika. ICE: https://www.incien.sk/cirkularna-ekonomika/, (2020)

8. Ministerstvo životného prostredia SR (MŽP SR), Obehové Slovensko. (MŽP SR): https://www.minzp.sk/spravy/2019/november/platforma-obehove-slovensko-chceprispiet-k-zmene-nasho-ekonomickeho-modelu.html, (2019)

9. A. Rashid, M. A. Farazee, P. Krajnik, C. Nicolescu, C. Resource conservative manufacturing. Journal of Cleaner Production, 57, 166-177. (2013)

10. Register EMAS v SR, https://www.emas.sk/register-emas-v-sr/, (2020)

11. K. H. Robért, G. Broman, G. Basile, Analyzing the concept of planetary boundaries from a strategic sustainability perspective: how does humanity avoid tipping the planet? Ecol. Soc. 18 (2):5. (2013)

12. Slovenská agentúra Životného prostredia (SAŽP), Čo je EMAS? SAŽP: https://www.sazp.sk/zivotne-prostredie/environmentalne-manazerstvo/schema-preenvironmentalne-manazerstvo-a-audit-emas/co-je-emas.html, (2020) 
13. Slovenská agentúra životného prostredia (SAŽP), Environmentálne vhodný produkt "EVP".

SAŽP:https://www.sazp.sk/zivotne-prostredie/environmentalnemanazerstvo/environmentalne-oznacovanie-produktov/narodna-znackaenvironmentalne-vhodny-produkt.html, (2020)

14. Slovenská agentúra životného prostredia (SAŽP). Environmentálna značka EÚ. $S A Z \check{P}$ :https://www.sazp.sk/zivotne-prostredie/environmentalnemanazerstvo/environmentalne-oznacovanie-produktov/environmentalna-znackaeu.html, (2020)

15. K. M. Srisruthi, Circular Economy. In International Journal of Trend in Scientific Research and Development (ijtsrd), Volume 1, Issue-6, (2017)

16. Trenčiansky samosprávny kraj (TSK), Zelená župa. TSK: https://www.tsk.sk/regionalny-rozvoj/zelena-zupa.html?page_id=323084, (2017)

17. V. S. C. Tunn, N. M. P. Bocken, E. A. van den Hende, J. P. L. Schoormans, Business models for sustainable consumption in the circular economy: An expert study. Journal of Cleaner Production, 212, 324-333. (2019) 